\title{
PREVALENCE OF GESTATIONAL DIABETES MELLITUS IN AN URBAN INDIAN COHORT USING DIABETES IN PREGNANCY STUDY GROUP IN INDIA (DIPSI) CRITERIA - VALIDATING ONE-STEP APPROACH
}

\author{
S. Khan', H. Bal' ${ }^{2}$ I. D. Khan'3 , D. Paul ${ }^{3}$ \\ 1 - INHS KALYANI, VISAKHAPATNAM, INDIA \\ 2 - D. Y. PATIL MEDICAL COLLEGE, PUNE, INDIA \\ 3 - ARMY COLLEGE OF MEDICAL SCIENCES AND BASE HOSPITAL, NEW DELHI INDIA
}

Background. India is the "World's Diabetes capital", with half the diabetic population being women. Early detection of glucose intolerance during pregnancy offers a timely opportunity for screening, management and prevention of gestational diabetes mellitus (GDM) and prevents fetal complications.

Objective. The study assessed the prevalence of GDM in an Indian cohort using the Diabetes in Pregnancy Study group of India (DIPSI) criteria.

Methods. 200 pregnant women underwent two-phase testing with non-fasting 75-gram glucose challenge under Diabetes in Pregnancy Study group of India (DIPSI) criteria at $<20$ weeks and between 24-28 weeks period of gestation. A 3-hour 100-gm oral glucose tolerance test (OGTT) was used for confirmation. Repeat testing was done for women negative during the first-phase.

Results. Mean age was $24.26 \pm 3.75$ years with $52.5 \%$ multigravidas. Mean Body Mass Index (BMI) was $20.7 \pm 3.07 \mathrm{~kg} / \mathrm{m}^{2}$. The prevalence of GDM in study cohort was found to be $15.5 \%$ using the DIPSI criteria while the prevalence of GDM after $100 \mathrm{~g}$ OGTT was 13.0\%. GDM was mostly seen to occur in women of 26-30-year age group. Statistically significant associations for age and GDM, and BMI and GDM were evidenced.

Conclusions. Maternal age of $\geq 25$ years should be adopted as a risk factor for the development of GDM. The DIPSI criteria offer a cost-effective and an evidence-based protocol for a single-step definitive glucose test for both screening and diagnosis of pregnant patients belonging to any socio-economic strata; furthering its implementation for public health obstetrics.

KEY WORDS: gestational diabetes mellitus; DIPSI criteria; screening; pregnancy; glucose tolerance test.

\section{Introduction}

Gestational Diabetes Mellitus (GDM) is established to be carbohydrate intolerance with onset or first diagnosis during pregnancy [1]. The WHO defines GDM as plasma glucose concentration of $>140 \mathrm{mg} / \mathrm{dl}$ 2-hours by 75 -gm oral glucose tolerance test (OGTT) similar to that of impaired glucose tolerance (IGT) test in a non-pregnant state [2]. With advancement of pregnancy, insulin resistance and diabetogenic stress caused by placental hormones necessitates compensatory increase in insulin secretion, the inadequacy of which leads to the development of GDM. The patients with GDM are at a risk group of future diabetes mellitus (DM) development, predominantly type-2 DM, as well as their children are [3]. In addition, untreated GDM may possibly lead to increased

Corresponding author: Dr Inam Danish Khan, MBBS, MD, DNB, DHCM, MIPHA, MISCD, Associate Professor (Clinical Microbiology and Infectious Diseases), Army College of Medical Sciences and Base Hospital, Delhi Cantt 110010 India

E-mail: titan_afmc@yahoo.com,

Mobile: +918076324060, Fax: +911125693490 risk of large for gestational age fetus, plunge in blood sugar and jaundice in the offspring.

The prevalence of DM is increasing worldwide. Developing countries sustain a major proportion of world population translating to the epidemic proportions of DM being encountered by the healthcare fraternity in limited resource public health infrastructure. India is projected as the "World's Diabetes capital", with half the diabetic population being women. India is expected to contain the highest population of diabetics by 2025 . The syndemic (synergistic epidemic) of DM and obesity compounding the problem of GDM exists under socio-epidemiological and anthropological perspectives of health disparity factored by poverty, living conditions, socio-economic status and dietary habits.

GDM is the most common metabolic disease of pregnancy worldwide. The prevalence of GDM reaches up to $14 \%$ of all pregnancies, resulting in approximately 200,000 cases annually in the United States. Asian and Indian 
lifestyles are starkly different from Western lifestyles translating into 11.3 times higher relative-risk of GDM in Indian women compared to their western counterparts [4].

With the population experiencing a changing lifestyle and epidemiology of DM, it is pertinent to offer screening of GDM during the antenatal work-up. GDM holds out a significant opportunity for testing, development and implementation of clinical strategies for diabetes prevention in people [5]. Timely screening of the pregnant women for glucose intolerance, succeeding euglycemia and adequate nutrition may prevent presumably the pathological cycle of vertical transmition of glucose intolerance. This necessitates the universal mandatory screening for GDM during pregnancy, which is a resource intensive concept in the developing country perspective. Presently most institutions catering to women with adequate affordability are following the 2-phase procedure for screening GDM. The criteria by Diabetes in Pregnancy Study Group of India (DIPSI) recommend a simplified onestep approach for the screening and diagnosis of GDMirrespective of fasting state of expectant mothers, which is a promising protocol for underprivileged communities having limited healthcare accessibility during pregnancy.

Timely revealing of glucose intolerance in pregnancy offers an opportunity for screening, management and prevention of GDM on time and prevents fetal complications thus improves neonatal outcomes $[6,7]$. This necessitates the general mandatory screening for GDM during pregnancy, which is a resource intensive testing modality. This study was carried out to assess the incidence of GDM in an Indian cohort using the DIPSI criteria [8].

\section{Methods}

The triple-blind study was conducted amongst 200 patients admitted to the antenatal outpatient department (OPD) of a tertiary-care hospital, containing 1600 beds, and medical teaching institute in Western India; the study was approved by the Ethics Committee of these medical facilities as well as the written informed consents were attained from the patients. All pregnant females at 20 weeks or less period of gestation (POG) were involved in the study that lasted for two years: from May 2012 to Apr 2014. The patients with GDM/Impaired Glucose Tolerance (IGT) in previous pregnancy, established morbidity of DM, DM in a first-degree relative or with a history of unexplained still- birth, large for gestational age offspring, congenital anomalies or previous birth injuries, were excluded. Relevant history, general examination for calculating body-mass index and evidence of insulin resistance along with obstetric/gynecological examination were carried out. Triple-blinding of a patient, gynecologist and laboratory medicine specialist was ensured to eliminate bias and confounding.

The entire cohort of 200 patients was subjected to a two-phase testing at the POG of $<20$ weeks and for a second time at the POG of 24-28 weeks, a temporal separation was at least four weeks. In the first phase, all patients were given 75-gm anhydrous oral glucose at their first visit, irrespective of their fasting state, according to the DIPSI criteria. The levels of plasma venous blood glucose were evaluated by glucose oxidase-peroxidase method in 2 hours. The indices of $\geq 140 \mathrm{mg} / \mathrm{dl}$ were positive by the DIPSI criteria. A 3-hour 100-gm oral glucose tolerance test (OGTT) was used for confirmation. Any indices of $\geq 95 \mathrm{mg} / \mathrm{dl}$ fasting, $\geq 180 \mathrm{mg} / \mathrm{dl}$ in 1 hour, $\geq 155 \mathrm{mg} / \mathrm{dl}$ in 2 hours, $\geq 140 \mathrm{mg} / \mathrm{dl}$ in 3 hours were considered to be positive. Only one positive value in OGTT was considered as IGT while two positive values were considered for GDM.

In the second phase, women who were negative initially by DIPSI criteria were made to undergo a repeat test with non-fasting 75-gm at 24-28 weeks as per the DIPSI criteria. A 100gm OGTT was used for confirmation.

Data was analyzed using SPSS (version 21; IBM Corporation) with $\chi^{2}$ test or Fisher's exact test for categorical variables and Student's t-test for continuous variables. All statistical tests were two-tailed and $\mathrm{P}$ values $<0.05$ were considered significant. Clinicodemographic and diagnostic profiles were correlated for descriptive statistics and included frequency, percentages and $95 \%$ confidence intervals (95\% CI).

\section{Results}

The study cohort comprised of young patients with mean age was $24.26 \pm 3.75$ years ranging from 20 to 28 years. Most patients were between 21 to 25 years of age (102/200, 51\%, $95 \%$ CI $43.87 \%-58.09 \%$ ), followed by $49 / 200$, $24.5 \%, 95 \%$ CI $18.83 \%-31.17 \%$, between 26 to 30 years $(24.5 \%)$ (Table 1$)$.

$95 / 200,47.5 \%, 95 \%$ CI $40.45 \%-54.65 \%$ were primigravida while $105 / 200,52.5 \%, 95 \%$ CI $45.35 \%-59.55 \%$ were multigravida. Mean Body Mass Index (BMI) was $20.7 \pm 3.07 \mathrm{~kg} / \mathrm{m}^{2}$, range 
between 14.33 to $30.81 \mathrm{~kg} / \mathrm{m}^{2}$. Most of the pregnant females $(108 / 200,54 \%, 95 \%$ CI $46.83 \%-61.01 \%$ ) were having BMI between 21-25 followed by $92 / 200$ (46\%, 95\% CI 38.99\% $53.17 \%$ ), who had BMI $\leq 20 \mathrm{~kg} / \mathrm{m}^{2}$. There were no overweight or obese women in the cohort (Table 2). The study was carried out with a 100\% follow up with no drop outs.

Out of the 200 pregnant females in the cohort, in the first phase, $31 / 200(15.5 \%, 95 \%$ CI $10.93 \%-21.44 \%$ ) were tested positive by the DIPSI criteria prior to 20 weeks POG; $21 / 200$ $(10.5 \%, 95 \%$ CI $6.77 \%-15.81 \%)$ of them were tested positive by 100-gm OGTT. In the second phase, the remaining 10 women tested positive by the DIPSI criteria and negative by $100-\mathrm{gm}$ OGTT were again subjected to $100-\mathrm{gm}$ OGTT at a 24-28-week POG, resulting in five more being found positive by 100-gm OGTT.

Out of the 169 women tested negative by the DIPSI criteria at less than 20 weeks POG, in the first phase, one aborted at 14 weeks POG and was excluded from the study. The remaining 168 women were again subjected to DIPSI and then validated by 100 -gm OGTT at a 24 -28-week POG. None tested positive with either DIPSI or 100-gm OGTT.

The prevalence of GDM in study cohort was found to be $15.5 \%$ using DIPSI criteria while the prevalence of GDM after 100-gm OGTT was 13\% (Table 1). GDM was mostly seen to occur in women of 26-30-year age group (12/26, 46.15\%, $95 \%$ CI $27.14 \%-66.25 \%)$ followed by $9 / 26$ $(34.62 \%, 95 \%$ CI $17.95 \%-55.64 \%)$ in the $21-25$ year age group. Statistically significant association for age and GDM ( $p=0.003$ ) was seen by Fisher's exact test. Almost all $(25 / 26,96.15 \%$, $95 \%$ CI $78.41 \%$ - 99.8\%) GDM was seen with BMI $>20 \mathrm{~kg} / \mathrm{m}^{2}$, with statistically significant $(p=0.003)$ difference seen by Fisher's exact test. However, the association of gravidity was not significant $(p=0.207)$ using Chi square test.

\section{Discussion}

Disorders of maternal glucose metabolism during pregnancy are two-pronged. Firstly, pre-existing type-2 DM accounts for $8 \%$ of DM in pregnancy. There is an increasing trend of type-2 DM in women of childbearing age group, attributable to sedentary lifestyles, dietary changes and the virtual epidemic of adolescent and childhood obesity.

GDM accounts for $90 \%$ of diabetes in pregnancy. GDM represents the "tip of an iceberg" for the overall prevalence of DM in the population, thus being representative screening target for timely intervention. The prevalence of GDM varies from $1-20 \%$ depending upon population sample and diagnostic criteria.

Risk factors of GDM include a high BMI (a measure of body fat), gaining weight or low physical activity in pregnancy, excessive dietary eating of polyunsaturated fats, glucose intolerance (a sign of diabetes) or delivery of a large baby in previous pregnancies, as well as a family history of diabetes. Excessive intake of saturated fat, low eating of polyunsaturated fat, and high gestational weight gaining may possibly increase the risk of GDM. A decreased risk of GDM is also associated with physical activity. Obesity is one of the most significant risk factors for GDM, its prevalence has been increasing much over the last decades $[9,10,11]$.

The study revealed GDM among young pregnant females up to 30 years of age in contrast to the development of DM in later age. The risk of GDM increases significantly from 25 years onwards [12]. The most predictive factor of GDM is maternal age $\geq 25$ years, according to the recommendations of the American Diabetes Association (ADA) on the age criteria of $\geq 25$ years as a cut-off for screening for GDM. In population with lower diabetes prevalence, timing of screening depends on the risk profile. Women at high risk are offered screening at

Table 1. Age profile of pregnant patients $(n=200)$

\begin{tabular}{|c|c|c|c|}
\hline Age (years) & Number of patients & Percentage (\%) & 95\% confidence intervals \\
\hline$\leq 20$ & 35 & 17.5 & $12.64-23.64 \%$ \\
\hline $21-25$ & 102 & 51.0 & $43.87-58.09 \%$ \\
\hline $26-30$ & 49 & 24.5 & $18.83-31.17 \%$ \\
\hline$>30$ & 14 & 7.0 & $4.03-11.71 \%$ \\
\hline
\end{tabular}

Table 2. Body-mass index (BMI) profile of pregnant patients $(n=200)$

\begin{tabular}{|c|c|c|c|}
\hline BMI (kg/m $\mathbf{~})$ & Number of patients & Percentage (\%) & $\mathbf{9 5 \%}$ confidence intervals \\
\hline$\leq 20$ & 92 & 46 & $38.99-53.17 \%$ \\
\hline $21-25$ & 108 & 54 & $46.83-61.01 \%$ \\
\hline$>26$ & 0 & 0 & - \\
\hline
\end{tabular}


first antenatal visit, moderate risk at 24-28 weeks as per ADA guidelines. In general, screening and diagnostic tests are performed between 24 and 28 weeks, because at this point in gestation the diabetogenic effect of pregnancy is manifested. The study of Kaiser Permanente of Colorado (KPCO) proved a strong cohort influence on the prevalence of GDM. Regardless of the age and ethnicity, the women, who were born more recently, were at an increased risk for GDM diagnosis compare to those born earlier. This finding most likely reveals an increased exposure to risk factors taking place before childbearing age [13]. In clinical practice, maternal age of $\geq 25$ years should be adopted instead of $\geq 35$ years or $\geq 40$ years as a risk factor for the development of GDM $[14,15]$.

The present study also proved that the increased prevalence of GDM was evidenced together with increasing BMI. Although the incidence of GDM in the pregnant females with normal weight (BMI 18.5-24.9) is $2.3 \%$, it increased more than five-fold to reach $11.5 \%$ in extremely obese pregnant women with BMI 35-64.9 $[16,17,18]$. A systematic review of observational studies published over last 30 years, which elected maternal BMI as the only measure of obesity and where all diagnostic criteria for GDM were accepted; it revealed that for every $1 \mathrm{~kg} / \mathrm{m}^{2}$ increase in BMI, the prevalence of GDM increased by $0.92 \%$ ( $95 \%$ CI $0.73 \%$ to $1.10 \%$ ) [19]. Indian women with GDM experience a higher risk of metabolic syndrome and diabetes [20].

The $15.5 \%$ prevalence of GDM by DIPSI criteria found in this study compares well to other Indian studies showing prevalence between $16.55 \%$ and $22 \%$. In India the prevalence of GDM has been estimated at $16.55 \%$ by the WHO criteria of a 2-hour blood glucose level of $140 \mathrm{mg} / \mathrm{dl}$. However, the prevalence for Kashmiri women was 3.8\% [21, 22, 23, 24, 25]. GDM was proved to be more widespread in urban areas than in rural. For this population and ethnicity, the incidence of GDM corresponds to the incidence of IGT in non-pregnant adults within that population [26]. In Indian context the prevalence of GDM is steadily increasing from $2 \%$ in 1982 to $12 \%$ in 1991 to $16.55 \%$ in 2002. Variations in prevalence of GDM due to geography and ethnicity have similarly been reported in Mexico [27].

Certain ethnically diverse subpopulations have a much higher rate of GDM which renders them the susceptibility of a greater predispo- sition to DM in later age. The incidence of GDM differs in direct share to the incidence of type2 DM for tis ethnic group or population. In Asian population, GDM reflects the prevalence of IGT in the population. Therefore, the general screening for GDM is necessary for Asian and Indian population [28]. In comparison to the selective screening, the general one for GDM distinguishes more patients and improves neonatal and maternal prognosis. Currently, and after extensive deliberation, universal screening of all pregnant women is recommended by some professional associations. Nevertheless, there exist challenges in quality control of laboratory testing in developing countries catering to mass-screening in resource limited laboratories, which needs to be taken into account for clinical decision making $[29,30]$.

In pregnancy, the choice to carry out a placebo-controlled trial involves clinical equipoise [31]. Hence, there was no control group of unmanaged pregnant women in this study, as there are some publications confirming that management of GDM women, as defined by the WHO criteria, was associated with a decreased risk of pregnancy outcome. As the routine screening for glucose intolerance during pregnancy was not done initially, probably the undiagnosed glucose intolerance that was occurring in the past has resulted in the increased prevalence of diabetes in India.

DIPSI criteria are a major advance as they cater diagnosis and screening of all pregnant women regardless of the fasting state by a single-step approach with a 75-gm of a 2-hour glucose test and a cut-off of $>140 \mathrm{mg} / \mathrm{dl}$ for diagnostics. The study revealed 31 patients through DIPSI criteria at $\leq 20$ weeks POG, 21 of which were detected by 100 -gm OGTT at $\leq 20$ weeks POG and five were detected between 24-28 weeks POG. If the 75-gm criterion was reapplied at 32-34 weeks POG as recommended by DIPSI, it is likely that even the five women, who tested negative, when validated with $100-$ gm OGTT, could have tested positive for GDM. DIPSI is very economical, practical, convenient and feasible for patients and obstetric healthcare practitioners $[32,33]$.

\section{Conclusions}

The incidence of Gestational diabetes mellitus in the study cohort using DIPSI criteria was significantly high (15.5\%) and is comparable with other Indian studies. In clinical practice, the maternal age of $\geq 25$ years instead of 35 
years or $\geq 40$ years should be adopted as a risk factor for GDM development. The DIPSI criteria offer a cost-effective and an evidence-based protocol for a single-stage complete glucose test for both screening and diagnosis of pregnant patients of any socio-economic strata; furthering its implementation for public health obstetrics.

\title{
ПОШИРЕНІСТЬ ГЕСТАЦЙНОГО ЦУКРОВОГО ДІАБЕТУ СЕРЕД КОГОРТИ МІСЬКОГО ІНДІЙСКОГО НАСЕЛЕННЯ ЗА КРИТЕРІЯМИ DIPSI - АПРОБУВАННЯ ОДНОЕТАПНОГО ПІДХОДУ
}

\author{
S. Khan', H. Bal', I.D. Khan'3, D. Paul ${ }^{3}$ \\ 1 - INHS KALYANI, VISAKHAPATNAM, INDIA \\ 2 - D. Y. PATIL MEDICAL COLLEGE, PUNE, INDIA \\ 3 - ARMY COLLEGE OF MEDICAL SCIENCES AND BASE HOSPITAL, NEW DELHI INDIA
}

Вступ. Індія є «столицею діабету у світі», при чому половину населення, хворого на діабет, складають жінки. Раннє виявлення порушення толерантності до глюкози під час вагітності дає моживість своєчасно проводити скринінг, лікування та профілактику гестаційного цукрового діабету (ГЦД) та запобігати розвиткові ускладнень вагітності. DIPSI.

Мета дослідження - встановити частоту розвитку ГЦД серед жінок з використанням критеріїв

Методи дослідження. Обстежено 200 вагітних жінок, яким проводили двофазне тестування навантаженням глюкозою (75 г глюкози натще серце) відповідно до критеріїв DIPSI на термінах <20 тижнів та між 24-28 тижнями вагітності. Тригодинний пероральний глюкозотолерантний тест (ПГТТ) (з навантаження 100г глюкози) використовували для повторного дослідження, яке проводили в тому числі і жінкам з негативними результатами, отриманими під час першої фази обстеження.

Результати. Середній вік обстежуваних вагітних жінок склав $(24,26 \pm 3,75)$ років, з них з 52,5\% - мали кілька вагітностей. Середній індекс маси тіла (IMT) становив $(20,7 \pm 3,07)$ кг/м². Встановлено, що поширеність ГЦД у досліджваній когорті становила 15,5 \% відповідно до критеріїв DIPSI, mоді як поширеність ГЦД після 100 г ПГТТ становила 13 \%. ГЦД в основному спостерігався у жінок вікової групи 26-30 років. Встановлено статистично достовірні кореляції між показниками віку та ГЦД, індексу маси тіла та ГЦД.

Висновки. Вік майбутньої матері більше 25 років повинен розглядатися як фактор ризику розвитку ГЦД. Критерії DIPSI - це економічно ефективний і обґрунтований протокол для викоримтання глюкозотолерантного тесту для скринінгу та діагностики вагітних пацієнток, що належать до будь-яких соціально-економічних верств, який може бути рекомендований для подальшої імплементації у клінічну практику.

КЛЮЧОВІ СЛОВА: гестаційний цукровий діабет; критерії DIPSI; скринінг; вагітність; глюкозотолерантний тест.

\section{References}

1. Metzger BE, Coustan DR. Summary and recommendations of the Fourth International WorkshopConference on Gestational Diabetes Mellitus: The Organizing Committee. Diabetes Care. 1998;21:B161-7.

2. Dirar AM, Doupis J. Gestational diabetes from A to Z. World journal of diabetes. 2017 Dec 15;8(12):489. doi:10.4239/wjd.v8.i12.489.
3. Varma K, Surwade VM, Sinha V, Kachhawa P. Prevalence of Gestational Diabetes And Risk Factors Among Women Visiting Antenatal Clinic of A Tertiary Health Care Hospital. IOSR Journal of Dental and Medical Sciences. 2017; 16(9):1-4.

4. Rosenblatt B. Prevalence, Health Behaviors, and Preventive Health Practices among Adult 
Coloradans with Diagnosed diabetes: Results from the Behavioral Risk Factor Surveillance System, 1997-2000. Denver, Colorado Department of Public Health. 2002.

5. Moon JH, Kwak SH, Jang HC. Prevention of type 2 diabetes mellitus in women with previous gestational diabetes mellitus. The Korean Journal of Internal Medicine. 2017;32(1):26-41. doi:10.3904/ kjim.2016.203.

6. Khan S, Bal H, Khan ID, Paul D. Evaluation of diabetes in pregnancy study group of India (DIPSI) criteria and Carpenter-Coustan criteria for diagnosis of gestational diabetes mellitus. Turkish J Obs Gyn. 2018; 15:75-79. 10.4274/tjod.57255.

7. Thomas A, Xiang A, Siri LK, Watanabe R. What is Gestational diabetes? Diabetes Care 2007 July; 30 (2): S105-111.

8. Seshiah V, Balaji V, Balaji MS. Scope for Prevention of Diabetes - Focus intrauterine milieu Interieur. Journal of Association of Physicians of India. 2008 Feb; 56: 109-113.

9. Luoto R, Kinnunen TI, Aittasalo M, Kolu P, Raitanen J, Ojala K, Mansikkamäki K, Lamberg S, Vasankari T, Komulainen T, Tulokas S. Primary prevention of gestational diabetes mellitus and large-for-gestational-age newborns by lifestyle counseling: a cluster-randomized controlled trial. PLoS medicine. 2011 May 17;8(5):e1001036.

10. Jovanovic L, Pettit DJ. Gestational diabetes mellitus. JAMA. 2001 Nov 28; 286(20): 2516-8.

11. Flegal KM. The obesity epidemic in children and adults: current evidence and research issues. Med Sci Sports Exerc 1999;31(Suppl. 11):S509-14.

12. Cousins L, Baxi L, Chez R, Coustan D, Gabbe S, Harris J, Landon M, Sacks D, Singh S. Screening recommendations for gestational diabetes mellitus. American journal of obstetrics and gynecology. 1991 Sep 1;165(3):493-6.

13. Van Zyl H, NS Levitt. Pregnancy outcome in patients with pregestational and gestational diabetes attending Groote Schuur Hospital, Cape Town, South Africa. S Afr Med J. 2018 Aug 28;108(9):772-6. doi: 10.7196/SAMJ.2018.v108i9.12992.

14. Wahabi H, Fayed A, Esmaeil S, Heba M, Kotb R. Prevalence and complications of pregestational and gestational diabetes in Saudi women: analysis from Riyadh Mother and Baby Cohort Study (RAHMA). BioMed Research International. 2017. https://doi. org/10.1155/2017/6878263.

15. Baptiste-Roberts K, Barone BB, Gary TL, Golden $\mathrm{SH}$, Wilson LM, Bass EB, Nicholson WK. Risk factors for type 2 diabetes among women with gestational diabetes: a systematic review. The American journal of medicine. 2009 Mar 1;122(3):207-14.

16. Seshiah V, Balaji V, Balaji MS, Panneerselvam A, Kapur A. Pregnancy and diabetes scenario around the world: India. Int J Gynaecol Obstet 2009 Mar; 104 suppl 1: S35-8.

17. Divakar H, Tyagi S, Hosmani P, Manyonda IT. Diagnostic criteria influence prevalence rates for gestational diabetes: implications for interventions in an Indian pregnant population. Perinatology:
Journal of Perinatal \& Neonatal Care. 2008 Nov $1 ; 10(6)$.

18. Seshiah V, Balaji V, Balaji MS, Paneerselvam A, Kapur A. Pregnancy and diabetes scenario around the world: India. International Journal of Gynecology \& Obstetrics. 2009 Mar 1;104(Supplement). S35-8.

19. Yu ZB, Han SP, Guo XR. Intelligence in relation to obesity: a systematic review and meta-analysis. Obes Rev. 2010 Sep; 11(9): 656-7.

20. Kale SD, Yajnik CS, Kulkarni SR, Meenakumari K, Joglekar AA, Khorsand N, Ladkat RS, Ramdas LV, Lubree HG. High risk of diabetes and metabolic syndrome in Indian women with gestational diabetes mellitus. Diabetic medicine. 2004 Nov;21(11):1257-8.

21. Gandhewar MR, Bhatiyani BR, Singh $P$, Gaikwad PR. A study of the prevalence of gestational diabetes mellitus and its maternal and fetal outcomes in a tertiary care hospital. Int J Reprod Contracept Obstet Gynecol. 2017 Sep;6(9):4011-4015. DOI: http://dx.doi.org/10.18203/2320-1770. ijrcog20174054

22. Zargar AH, Sheikh MI, Bashir MI, Masoodi SR, Laway BA, Wani AI, Bhat MH, Dar FA. Prevalence of gestational diabetes mellitus in Kashmiri women from the Indian subcontinent. Diabetes research and clinical practice. 2004 Nov 1;66(2):139-45.

23. Wahi P, Dogra V, Jandial K, Bhagat R, Gupta R, Gupta S, Wakhloo A, Singh J. Prevalence of gestational diabetes mellitus (GDM) and its outcomes in Jammu region.J Assoc Physicians India. 2011 Apr;59(4):227-30.

24. Choudhary N, Rasheed M, Aggarwal V. Prevalence of gestational diabetes mellitus, maternal and neonatal outcomes in a peripheral hospital in North India. Int J Res Med Sci. 2017 Jun;5(6):23432345. DOI: http://dx.doi.org/10.18203/2320-6012. ijrms20172034

25. Reddy KM, Lakshmi SP, Balmuri S, Jagarlamudi A, Betha K. Prevalence of gestational diabetes mellitus and perinatal outcome: a rural tertiary teaching hospital-based study. Int J Reprod Contracept Obstet Gynecol. 2017 Aug;6(8):3594-3598. DOI: http://dx.doi.org/10.18203/2320-1770. ijrcog20173491.

26. Tripathi R, Verma D, Gupta VK, Tyagi S, Kalaivani M, Ramji S, Mala YM. Evaluation of $75 \mathrm{~g}$ glucose load in non-fasting state [Diabetes in Pregnancy Study group of India (DIPSI) criteria] as a diagnostic test for gestational diabetes mellitus. The Indian journal of medical research. 2017 Feb;145(2):209014. Doi: 10.4103/ijmr.IJMR_1716_15.

27. Forsbach G, Vázquez-Lara J, Alvarez-y-García C, Vázquez-Rosales J. Diabetes and pregnancy in Mexico. Revista de investigacion clinica; organo del Hospital de Enfermedades de la Nutricion. 1998;50(3):227-31.

28. Lao TT, Ho LF, Chan BC, Leung WC. Maternal age and prevalence of gestational diabetes mellitus. Diabetes Care. 2006; 29(4): 948-9.

29. Khan ID, Gupta N, Rangan NM, Singh $R_{\text {, }}$ Sharma AK, Khurana A, Rudra P, Krushnarao MS. Evaluation of pre and post analytical variables in clinical microbiology services in multidisciplinary ICU 
of a medical college and tertiary care hospital. Journal of Basic and Clinical Medicine. 2016 Apr $5 ; 5(1) .2-4$.

30. Khan ID, Khan SA, Asima B, Hussaini SB, Zakiuddin M, Faisal FA. Morbidity and Mortality amongst Indian Hajj pilgrims: A 3-year experience of Indian Hajj Medical Mission in Mass-Gathering Medicine. Journal of Infection and Public Health. 2017 Jun 28. Pii: S1876-0341(17)30147-8. http://dx.doi. org/10.1016/j.jiph.2017.06.004

31. Gifford F. Uncertainty about clinical equipoise. Clinical equipoise and the uncertainty principles both require further scrutiny. BMJ 2001; 322:795.
32. Khan S, Khan ID. The Pregnant Indian pilgrim at Hajj and associated obstetric and neonatal outcomes: A 3-year experience of Indian Hajj Medical Mission. Sultan Qaboos Univ Med Journal. Epub Ahead of print. 2018, eISSN 2075-0528, ISSN 2075051X. DOI: 10.18295/squmj

33. Vij $P$, Jha S, Gupta SK, Aneja A, Mathur R, Waghdhare S, Panda M. Comparison of DIPSI and IADPSG criteria for diagnosis of GDM: a study in a north Indian tertiary care center. International Journal of Diabetes in Developing Countries. 2015 Sep 1;35(3):285-8. 